DOI 10.37882/2223-2982.2021.03.04

\title{
КОГНИТИВНО-КОММУНИКАТИВНЫЙ ПОДХОД ОБУЧЕНИЯ АНГЛИЙСКОЙ МЕДИЦИНСКОЙ РЕЦЕПТИВНОЙ ЛЕКСИКЕ
}

\section{COGNITIVE-COMMUNICATIVE APPROACH TO TEACHING ENGLISH MEDICAL RECEPTIVE VOCABULARY \\ L. Arzumanyan T. Asatryan \\ N. Arutyunyan \\ A. Gevorgyan \\ T. Mantashyan}

Summary: This article analyzes the cognitive-communicative approach of teaching English medical receptive vocabulary in non-linguistic universities. The article considers the development of skills in the context of teaching English as a language of professional communication, as well as obtaining new knowledge on the subject. Therefore, the question arises of using a cognitive strategy and methodology to master the deep meanings of the content structures of the text, embodying the motives for forming the skills of adequate perception of text information and creating their own (oral and written) statements.

Keywords: receptive view, medical texts, a set of exercises and tasks, authentic material, cognitive approach, professional vocabulary, competence, communicative approach.
Арзуманян Лиана Сержиковна

Преподаватель, Ереванский государственный медицинский университет им. М. Гераци,

Армения, г. Ереван

lianaarzoumanyan@gmail.com

Асатрян Такуи Калдазуновна

Преподаватель, Ереванский государственный медицинский университет им. М. Гераци,

Армения, г. Ереван

Арутюнян Нарине Степановна

Преподаватель, Ереванский государственный медицинский университет им. М. Гераци,

Армения, г. Ереван

Геворгян Анаит Маратовна

Преподаватель, Ереванский государственный медицинский университет им. М. Гераци,

Армения, г. Ереван

Манташян Тамара Эдуардовна

Преподаватель, Ереванский государственный медицинский университет им. М. Гераци,

Армения, г. Ереван

Аннотация: В данной статье анализируется когнитивно- коммуникативный подход обучения английской медицинской рецептивной лексике в неязыковых вузах. Рассматривается развитие навыков в контексте обучения английскому как языку профессионального общения, а также получения новых знаний по предмету. Поэтому, встает вопрос использования когнитивной стратегии и методики, чтобы овладеть глубинными значениями содержательных структур текста, воплощающих мотивы для формирования умений адекватного восприятия текстовой информации и создания собственных (устных и письменных) высказываний.

Ключевые слова: рецептивный вид, медицинские тексты, комплекс упражнений и заданий, аутентичный материал, когнитивный подход, профессиональная лексика, компетентность, коммуникативный подход.

образования речь идет о способности осуществлять профессионально направленную коммуникацию средствами английского языка, тогда как успешность работы в сфере медицины напрямую зависит от знания соответствующей лексики [12: с.2270].

В свою очередь, коммуникативный подход создает условия для сознательно-речевой деятельности, где речевая практика основывается не только на знаниях языковой системы, но и на деятельности общения. Коммуникативный подход стал главной целью учебного процесса - формирование коммуникативной компетенции, основанной на знаниях, умениях познавательного и творческого типа, социальных навыках, мировоззренческих убеждениях [7: с. 126]. При этом, однако, необхо- 
димо осознавать, что несмотря на тот факт, что специальный язык -это вербальный язык, его характерной особенностью является достаточно развитая тенденция к привлечению в его состав авербальных средств, использующихся в функции его дефиниции, как дополнительный материал в виде рисунков, чертежей, схем и т.д.

Под когнитивной стратегией понимают совокупность взаимосвязанных и взаимообусловленных способов и средств освоения языковых единиц как основы познания и формирования концептуальной и языковой картины мира и определенного результата создания образа мира в воображении каждого [14: с. 4]. Сущность когнитивной стратегии заключается в толковании учебных языковых единиц как концептов - носителей этнокультурной информации, особых сигналов конкретного мира. Целью когнитивной стратегии и методики является овладение глубинными значениями содержательных структур текста, воплощающих мотивы автора для формирования умений адекватного восприятия текстовой информации и создания собственных (устных и письменных) высказываний в соответствии с коммуникативной целью и намерениями, развития познавательной активности, повышения интереса к изучению английского языка, воспитания национального самосознания, уважения к языковым традициям носителей английского языка [15: с. 52]. Интерес к когнитивно-коммуникативному обучению и стратегиям его реализации в контексте высшего образования постепенно растет. Проблема обучения иностранным языкам рассматривается не как обучение собственно лингвистическим знаниям, а как трансляция знаний о мире. Рассматривая когнитивный аспект овладения иностранным языком, А. Леонтьев подчеркивает, что овладевая иностранным языком, мы одновременно усваиваем присущий соответствующему народу образ мира, то или иное видение мира в рамках национальной культуры, одним из важнейших компонентов которой является язык. По мнению А. Леонтьева, основная задача овладения иностранным языком в когнитивном аспекте состоит в том, чтобы научиться осуществлять ориентирование так, как это делает носитель языка [5: с. 225]. А значит, когнитивно-коммуникативный подход к обучению языку, сформировавшийся на базе ведущих идей указанных методик, является одним из самых приоритетных в реализации высшего образования.

Целью обучения чтению в неязыковых вузах является достижение такого уровня чтения, которое обеспечивает достаточное понимание содержательной информации в письменных источниках [6: с.68].

Профессионально ориентированное чтение на английском языке признается важным, поскольку владение именно этим видом речевой деятельности входит в интересы будущего специалиста, поскольку иноязычное чтение является основным средством получения инфор- мации с целью дальнейшего использования в профессиональной деятельности. Навыки зрелого чтения иноязычных текстов могут быть развиты уже на начальном этапе изучения английского языка в неязыковом вузе, если использовать когнитивно-коммуникативную стратегию, построенную на психокогнитивной модели декодирования информации по принципу «сверху-вниз», от более высокого уровня (фоновые знания, ожидания читателя) к распознаванию лексико-грамматических форм.

А. Джонс выделяет пять ключевых понятий, характеризующих когнитивный подход к обучению чтению в целом: схемы, интерактивность, смысловая обработка текста, набор читательских стратегий, метакогнитивная осознанность [11: с.95]. Эффективность когнитивнокоммуникативной методики обучения обеспечивается комплексом упражнений, в котором учитываются индивидуально-личностные, когнитивные стили и стратегии студентов. С помощью когнитивно-коммуникативной методики обучения чтению на иностранном языке можно сократить путь овладения большим объемом профессионально-ориентированной англоязычной информации, необходимой студенту, а также улучшить скорость и качество ее изъятия для дальнейшего использования.

Умение аннотировать профессионально-ориентированные тексты является одним из требований Программы по английскому языку для профессионального общения, согласно которой обучение аннотированию (на родном и иностранном языках) должно быть направлено на выработку навыков и умений оформления полученной информации [10: с.183]. К наиболее весомым принципам когнитивно-коммуникативной стратегии относятся:

- принцип целостного восприятия текста; принцип функциональности;

- принцип профессиональной ориентации и тематической серийности;

- принцип интегративной речевой деятельности;

- принцип системности;

- принцип формирования стратегий учебной деятельности.

Основным методическим принципом при обучении аннотированию считается принцип целостного восприятия текста. Когнитивная психология доказывает, что воспринимать информацию легче, если студент представляет, что именно он будет изучать [8: с.17]. Поэтому при когнитивно-коммуникативном подходе анализ начинается с текста в целом и направлен на выявление его макроструктуры, которая материализуется студентами в виде текстовой матрицы. После того, как составлена текстовая матрица, начинается работа с его лексико-грамматическими единицами, что побуждает студентов к использованию языковой догадки на основе контекста. 
В Ереванском государственном медицинском университете имени Мхитара Гераци, при обучении английскому языку как неязыковой вуз, целесообразно уделяется большое внимание чтению специальных текстов, чтобы студенты в дальнейшем могли читать медицинскую литературу на иностранном языке без особых трудностей. Как считают Г.А. Гринюк и Ю.О. Семенчук, «аутичные тексты являются» накоплением словарного запаса студентов по специальности, примером использования терминологической лексики в контексте, что помогает конкретизировать значение слов, объяснить и уточнить примеры их использования в соответствии с языковыми нормами и стандартами» [3: с. 30]. В ЕГМУ английский язык изучают студенты в течении одного года на первом курсе. Основной учебник, по которому ведется обучение студентов английскому языку - "Nursing 1, Nursing 2", а также, в качестве дополнительного материала для чтения предлагаются аутентичные тексты по специальности из книги - "А short course of Medical terminology" под редакцией Davi-Ellen Chabner. Студенты - медики проходят различные тексты по теме: The structure of the human body, Infectious diseases, Immune system, Diagnostic tests and procedures and etc. Например, на основе этих текстов выполняются некоторые задания по чтению во время урока:

1. Complete the following sentences using the medical terms given below.

$$
\begin{array}{lll}
\text { diagnosis } & \text { erythrocytes } & \text { hepatitis } \\
\text { gynecology } & \text { hematoma } & \text { prognosis }
\end{array}
$$

a) A mass of blood, o black and blue mark is a/an...........

b) A red blood cell is a /an ..............

c) The study of women is ......

2. Give the meanings of the following terms.
a) gastritis
b) oncologist
c) laparotomy
d) rhinitis

3. Complete the following medical terms related to the stomach.
a) Pain in the stomach
b) Inflammation of the stomach
c) Process of visually examining
d) Incision of the stomach

$$
\begin{aligned}
& \text { gastr........ } \\
& \text { gastr....... } \\
& \text { gastr........ } \\
& \text { gastr....... }
\end{aligned}
$$

4. In the following medical vignettes, circle the bold term that best completes the meaning of the sentences.

a) Selma ate a spicy meal at an Indian restaurant. Later that night she experienced (osteoarthritis, dermatitis, gastroenteritis). Fortunately the cramping and diarrhea subsided by morning. b) When Mr. Saluto collapsed and died while eating dinner, the family requested (a/ an laparotomy, gastroscopy, autopsy) to determine the cause of death. The (hematologist, pathologist, gastroenterologist) discovered that Mr. Saluto had died of (cardiovascular accident, dysentery, cerebrovascular accident), otherwise known as a stroke.

\section{Answer the following questions according to} the text.

1. What are the words used when doctors talk about the main parts of the digestive system?

2. What are the main parts of the respiratory system?

3. What does the airway consist of?

\section{Examination of the abdomen}

a) Complete the textbook extract according to the text.

To examine the patient for enlarged abdominal ...... first feel for the....and the.......on the right side. To do this, ask the patient to take a deep breath, while passing with fingers upwards and inwards. Next, feel for the right ........and then cross over for the left.

\section{b) Tell the text to each other. Work in pair.}

Принцип интегративности речевых видов деятельности, то есть взаимосвязанное формирование навыков чтения, формирует и закрепляет лексико-терминологическую систему профессионального регистра студентов. На более продвинутой ступени обучения профессионально-ориентированному иностранному языку - анализ текста служит прагматической цели поиска информационных ассоциаций, а различные упражнения помогают действительно почувствовать "вкус языка".

Подводя некоторые итоги, подчеркнем, что сегодня язык из специальности все больше превращается в язык для профессиональной деятельности. При обучении студентов-медиков иностранному языку заключается в разработке профессионально - ориентированного комплекса упражнений и заданий, способствующие повышению уровня знания языка и профессиональной компетентности выпускников неязыковых вузов. Учитывая когнитивность в обучении языку предполагает учет таких категорий, как знание, познание, мышление, восприятие, интеллект, а также развитие познавательной активности, повышение интереса к изучению английского языка [13: с. 27]. Мы абсолютно уверены, что только разумное сочетание старого и нового, стереотипов и творчества, умения и вдохновения может привести кжелаемому профессиональному успеху, выводя студентов на новый качественный уровень межкультурного профессионального общения. 


\section{ЛИТЕРАТУРА}

1. Абрамян С.А. Роль профессионально ориентированного обучения иностранному языку в формировании межкультурной компетенции Текст. / С.А. Абрамян // Вопросы прикладной лингвистики: сб. науч. трудов. - М.: РУДН, 2009. - 154с

2. Бурова Ч.Н. Базовые понятия языка фармации: терминологический и когнитивно-прагматический аспекты. Известия РГПУ им А.И. Герцена. Общественные гуманитарные науки. 2008. № 11 (75). С. 7-15.

3. Гринюк Г.А., Семенчук Ю.О. Коммуникативный подход в современных технологиях обучения иностранному языку. № 2. 2007. - С. 30 - 34.

4. Лебедева М.В. Когнитивно-коммуникативный подход в обучении лексико-грамматическому аспекту устной речи студентов переводческого факультета /М.В. Лебедева // Когнитивные процессы в иноязычном словоупотреблении и слововосприятии на уроках иностранного языка в школе и вузе: Межвуз. сб. науч. статей. - Н. Новгород: НГЛУ имени Добролюбова, 2004. - С. 88-93.

5. Леонтьев А.А. Основы психолингвистики / А.А. Леонтьев. - М. : Смысл, 1997. - 287 с.

6. Майборода С.В. Коммуникативно-когнитивный подход в обучении связной речи иностранных студентов-медиков // Педагогика высшей школы. - 2016. - №1. - C. 66-68.

7. Скрябина 0.А. Когнитивно-коммуникативный подход в обучении правописанию как текстооформляющей деятельности: монография / 0.А. Скрябина. Ряз. гос. ун-т им. С.А. Есенина. - Рязань, 2009. - 404 с.

8. Солсо Р. Когнитивная психология / Р. Солсо. - Питер, 2006. - 588 с.

9. Davi-Ellen Chabner. Medical Terminology. 7 th edition. USA . 2015.

10. Hutchinson T. and A. Waters. English For Specific Purposes: A Learning-Centred Approach. - Cambridge: Cambridge University Press, 1987. - 183 p.

11. Johns Ann M. The current situation // Responses to English for Specific Purposes, Ed. Peter Master. - San Jose University, 1998. -242 p.

12. Kulgildinova, T \& Klara, Kunakova \& Kulyay, Zhaxylikova \& Yelubayeva, Perizat \& Languages, Russian \& Kazakhstan, Almaty \& Khan, Kazakh. (2017). Integration of the cognitive and communicative approach in the practice of language education of students. 2260-2270.

13. Krashen S. D. Principles and Practice in Second Language Acquisition. Oxford: Pergamon Press. 1982-

14. Newby D.A Cognitive+Communicative Theory of Pedagogical Grammar. Habilitationsschrift. Karl-Franzens Universität Graz. 2003

15. Skehan P. A Cognitive Approach to Language Learning. Oxford: Oxford University Press. 1998

() Арзуманян Лиана Сержиковна (lianaarzoumanyan@gmail.com), Асатрян Такуи Калдазуновна, Арутюнян Нарине Степановна, Геворгян Анаит Маратовна, Манташян Тамара Эдуардовна.

Журнал «Современная наука: актуальные проблемы теории и практики»

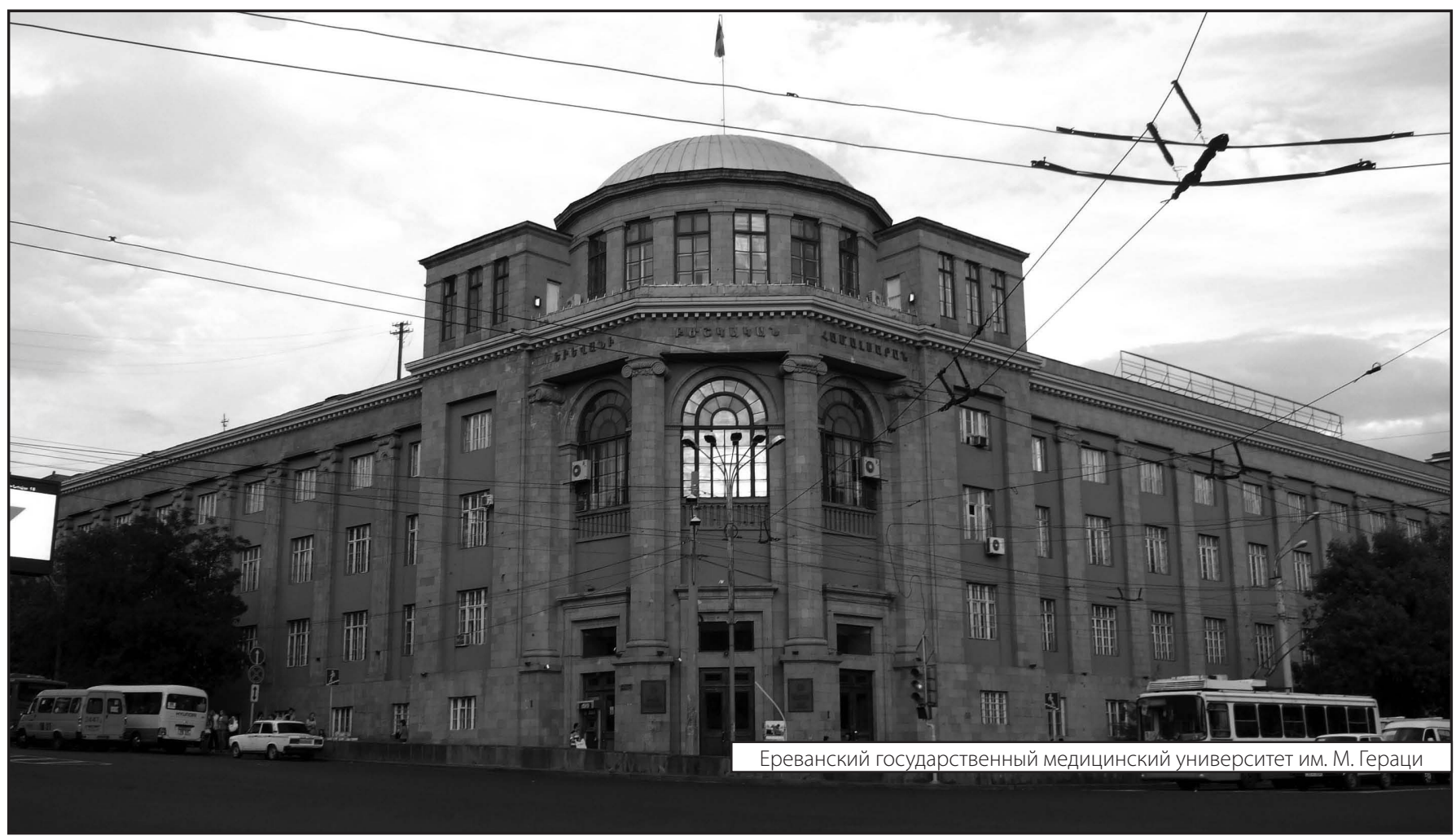

